\title{
Zamki krzyżackie i biskupie na ziemi chełmińskiej - nowe źródła, nowe perspektywy
}

Od 2005 roku w Zakładzie Archeologii Architektury Instytutu Archeologii UMK w Toruniu realizowany jest program badawczy „Zamki ziemi chełmińskiej" (il. 1). Jest on próbą odpowiedzi na podstawowe pytania związane z początkami krzyżackiej murowanej architektury obronnej na ziemi chełmińskiej. Dotyczą one m.in.: określenia początków aktywności budowlanej, chronologii i obecności osadnictwa poprzedzającego przybycie Krzyżaków, form najstarszych budowli, lokalizacji i funkcji pomieszczeń, kultury materialnej oraz szczegółów i technik budowy warowni ${ }^{1}$.

1 Maciej Majewski, Bogusz WasiK, Marcin WiewióRA, Studia nad warsztatem budowlanym zamku biskupów chełmińskich w Wąbrzeźnie, „Wiadomości Konserwatorskie”, 38, 2013, s. 54-65; Agata Момот, Bogusz WasıK, Marcin WiewióRA, Zamek krzyżacki w Papowie Biskupim. Nowe odkrycia i nowe interpretacje, „Rocznik Grudziądzki”, 22, 2014, s. 65-98; Bogusz WAsIK, Zabudowa zamku górnego i przedzamczy na podstawie źródeł pisanych i ikonograficznych z XVI-XVIII wieku, [w:] Zamek w Grudziq̨dzu. Studia i materiały, red. Marcin Wiewióra, Toruń 2012 (dalej cyt.: ZAMEK w GRUdziąDZU 2012), s. 57-71; TENŻE, Prace budowlane na zamkach w Grudziądzu i Toruniu u progu XIV wieku. Przyczynek do badań nad średniowiecznymi warsztatami budowlanymi w Prusach, „Rocznik Grudziądzki”, 22, 2014, s. 99-112; TENŻE, Analiza źródeł architektonicznych, [w:] Zamek biskupów chelmińskich w Wąbrzeźnie. Studia i materiały, red. Marcin Wiewióra, Torun 2014 (dalej cyt. Zamek BISkupów w WĄBRzeźnie 2014), s. 87-98; Marcin WiewIÓRA, Badania archeologiczno-architektoniczne średniowiecznego zamku w Papowie Biskupim, w ziemi chelmińskiej, „Archaeologia Historica Polona”, 17, 2007, s. 293-306; TENŻE, Nowe źródła do dziejów zamku biskupów w Wąbrzeźnie, „Rocznik Grudziądzki”, 20, 2012, s. 11-30; TENŻE, Zamki krzyżackie na ziemi chetmińskiej w świetle najnowszych badań wybranych obiektów, „Kwartalnik Architektury i Urbanistyki", 58, 2013, z. 1, s. 97-123. 


\section{Metody}

W ciągu dziesięciu lat w różnym zakresie przebadano pięć budowli: w latach 2005-2008 i 2012 - zamek w Papowie Biskupim, w roku 2009 - fragment zachodniej części zamku w Radzyniu Chełmińskim, w latach 2008-2009 - dom konwentu w Grudziądzu, w latach 2011-2012 zamek i przedzamcze zamku biskupów chełmińskich w Wąbrzeźnie, a w 2013 roku zainicjowano, kontynuowane, badania zamku w Kowalewie Pomorskim². Zakres prac badawczych był zróżnicowany, dostosowany do warunków i specyfiki stanowiska, planu badań oraz funduszy. Wykopy szerokoprzestrzenne eksplorowano podczas badań zamków w Grudziądzu, Radzyniu Chełmińskim, Papowie Biskupim i Kowalewie Pomorskim oraz w Wąbrzeźnie.

Wykopy sondażowe założono na przedzamczu zamku w Wąbrzeźnie, Kowalewie Pomorskim oraz w Papowie Biskupim. Ich uzupełnieniem były odwierty geologiczne realizowane podczas wstępnego rozpoznania terenu (Wąbrzeźno, Kowalewo Pomorskie - przedzamcza) oraz prace geologiczne, niezbędne do analiz specjalistycznych środowiska przyrodniczego i rekonstrukcji środowiska (Grudziądz - dom konwentu, Papowo Biskupie - parcham południowy i przedzamcze).

Od początku program badawczy realizowany był w ramach interdyscyplinarnego zespołu badawczego. Głównym założeniem było kompleksowe rozpoznanie warowni, tak pod względem archeologicznym, jak i historycznym oraz przyrodniczym. Do współpracy zaproszono historyków z Instytutu Historii i Archiwistyki UMK w Toruniu, geologów i geomorfologów z Instytutu Geografii UMK $w$ Toruniu, archeologów różnych specjalności oraz specjalistów z zakresu archeozoologii, palinologii i dendrochronologii. Badania przyrodnicze (archeozoologia, geomorfologia, palinologia, dendrochronologia) zawierały rekonstrukcję środowiska przyrodniczego w okresie budowy zamków, analizę kości zwierzęcych (gospodarka żywieniowa, produkcja, struktura spożycia) i analizę dendrochronologiczną pobranych próbek drewna. Badania archeologiczne objęły analizy stratygrafii, synchronizację warstw kulturowych i analizę źródeł ruchomych. Na tej podstawie podjęto próbę określenia chronologii oraz etapów budowy poszczególnych elementów zamków.

Ogromne znaczenie dla realizacji najważniejszych założeń programu badawczego miały nowe, krytyczne analizy dostępnych źródeł historycznych, które w wielu przypadkach dostarczyły nowych informacji, bądź zweryfikowały

\footnotetext{
2 Na temat wyników badań zamku w Kowalewie - zob. artykuł Bogusza Wasika w niniejszym tomie.
} 
dotychczasowe poglądy na temat początków prac budowlanych, rozplanowania i funkcji pomieszczeń oraz zakresu prac budowlanych i ich poszczególnych etapów ${ }^{3}$.

Ostatnim elementem badań były analizy architektoniczne, które stały się podstawą do wnioskowania na temat warsztatu budowlanego, technik budowlanych oraz szczegółów budowy danych warowni. Problem ten okazał się bardzo ważny z uwagi na istotne różnice stwierdzone pomiędzy dziewiętnastowiecznymi, utrwalonymi w literaturze przedmiotu wizjami zamków a faktycznymi wymiarami i detalami tych budowli, stwierdzonymi podczas analizy wyników badań.

\section{Pytania, hipotezy, założenia badawcze}

Od wielu lat toczy się w literaturze przedmiotu dyskusja na temat schematu rozwoju osadnictwa warownego zakonu krzyżackiego. Spory dotyczyły zwłaszcza zagadnienia związków pomiędzy osadnictwem przedkrzyżackim (zarówno w kontekście Słowian, jak i plemion pruskich), a budową murowanych warowni krzyżackich. Problem ten jest znacznie szerszy, zakładano bowiem również, że niektóre murowane warownie powstawały na wcześniejszych drewnianych warowniach krzyżackich, które sukcesywnie zastępowane były budowlami wznoszonymi z cegły i kamienia. Opierano się przy tym głównie na skąpych przekazach źródłowych, w których wzmiankowane są grody - castra - w miejscu późniejszych murowanych zamków krzyżackich. W niewielkim tylko stopniu informacje te zostały wspatre wynikami badań archeologicznych, do tej pory prowadzonych w ograniczonym zakresie zaledwie na kilku obiektach, m.in. w Toruniu (gdzie potwierdzono istnienie osadnictwa wczesnośredniowiecznego o charakterze grodowym), podobnie w Pokrzywnie oraz w Lipienku (gdzie znaleziono, co prawda, ślady osadnictwa wczesnośredniowiecznego, ale nie wyjaśniono charakteru osadnictwa poprzedzającego powstanie murowanego zamku ${ }^{4}$. W Grudziądzu już w latach 40. XX wieku odkryto relikty wczesno-

\footnotetext{
3 Sławomir JóźwIAK, Janusz TrupINDA, Krzyżacki zamek komturski w Grudziądzu w średniowieczu na podstawie źródeł pisanych. Chronologia powstania i układ przestrzenny, [w:] ZAMEK w GRudzIĄDzu 2012, s. 49-71; Sławomir JóźwiAK, Janusz TRUPINDA, Zamek biskupów chełmińskich w Wabrzeźnie na podstawie źródeł pisanych. Chronologia budowy i układ przestrzenny, [w:] ZAMEK BISKUPów w WĄBRzEźnIE 2014, s. 49-56.

4 Jacek BoJARSKI, Lipienek, [w:] Wczesnośredniowieczne grodziska ziemi chelmińskiej. Katalog źródel, red. Jadwiga CHudzIAKOwa, Toruń 1994, s. 92-102; Jadwiga CHudzIAKOwA, Osadnictwo przedkrzyżackie na wzgórzu zamkowym w Toruniu w świetle ostatnich badań archeologicznych (1958-1961), „Zapiski Historyczne poświęcone historii Pomorza”, 28, 1963, z. 4, s. 591-600; Ryszard Boguwolski, Pokrzywno - Zamek, pow. Grudziądz. Stanowisko 1, „Informator Archeologiczny: Badania”, 8, 1974, s. 191-192; Ryszard BoguwolskI, Marian Kochanowski, Sprawozdanie z arche-
} 
średniowiecznej osady, nieprzesądzającej jednak o jej charakterze (gród, osada otwarta), niepozwalającej również na bardziej precyzyjną chronologię. W przypadku pozostałych obiektów prace archeologiczne o charaterze sondażowym, przede wszystkim z powodu ich ograniczonego zakresu, nie zwerfikowały takich przypuszczeń. Przykładowo w Golubiu odkryto ślady wczesnośredniowiecznego osadnictwa, które nie dają jednak podstaw do formułownia bardziej szczegółowych wniosków na temat istnienia $w$ tym miejscu grodu ${ }^{5}$. W wielu wypadkach istotnym ograniczeniem było także niefortunne umiejscowienie wykopów sondażowych - o niewielkich wymiarach, zakładanych z reguły w miejscach, gdzie następowała największa akumulacja materiału rozbiórkowego (gruzu). Jedynym efektem takich poszukiwań była gruba warstwa gruzu ceglanego, uniemożliwiająca przebicie się do istniejących - bądź nie - wcześniejszych poziomów osadniczych. Jest to problem istotny, ponieważ podnoszona w dyskusji kwestia istnienia wcześniejszego osadnictwa grodowego w miejscu późniejszych warowni krzyżackich dotyczy także wielu innych obiektów leżących poza ziemią chełmińską. Dopóki jednak nie zostaną przeprowadzone w tych miejscach badania archeologiczne, nie zostanie on pozytywnie zweryfikowany (udało się to zrobić ostatnio na przykład w Gdańsku). Do najistotniejszych zagadnień należą zatem pytania: czy zamki powstawały w miejscu wcześniejszych osad obronnych? Jak wyglądały etapy ich budowy - faza drewniana i murowana? Czy najstarsze zamki (nieregularne) powstawały przy wykorzystaniu takich samych metod / / technik budowlanych jak młodsze obiekty (regularne) i na czym one polegały?

Ważnym elementem badań była weryfikacja planów budowli funkcjonujących w niektórych przypadkach od drugiej połowy XIX wieku, które aż do początku XXI wieku nigdy nie były przedmiotem badań archeologiczno-architektoniczych. Przeprowadzono więc ponowną analizę układów przestrzennych obiektów, wykorzystując do tego celu dostępne informacje historyczne (źródła średniowieczne, wizytacje, lustracje itp.), a przede wszystkim - nowe dane, pochodzące z badań archeologicznych i architektonicznych.

Ostatnią kwestią w kontekście badań archeologicznych była próba weryfikacji chronologii zamków. Było to jednocześnie najtrudniejsze zadanie, bowiem wcześniejsze, zrealizowane w latach 50., 60. i 70. XX wieku prace archeologiczne wykazały, że ten typ obserwacji w niewielkim tylko stopniu może wprowadzić

ologicznych badań na terenie zespołu zamkowego w Pokrzywnie, gm. Gruta, maszynopis w archiwum Muzeum im. ks. dr. Władysława Łęgi w Grudziądzu.

5 Krzysztof NowiŃski, Opis stratygrafii i murów z badań archeologicznych w 1967 r. w Golubiu-Dobrzyniu, woj. bydgoskie, [mps], Toruń 1967, Archiwum WUOZ w Toruniu; TEnżE, Badania archeologiczno-architektoniczne w Golubiu-Dobrzyniu, „Wiadomości Archeologiczne”, 34, 1969, z. 1, s. 180-183; TENŻE, Wyniki badań archeologiczno-architektonicznych zamku pokrzyżackiego w Golubiu-Dobrzyniu w latach 1967-1969, „Komunikaty Archeologiczne”. Badania archeologiczne na terenie województwa bydgoskiego w latach 1968-1969, Bydgoszcz 1972, s. 140-149. 
istotne zmiany w dotychczasowej chronologii tych obiektów bez wsparcia ze strony innych badań specjalistycznych.

\section{Analiza}

Ponieważ szczegółowe wyniki badań omawianych budowli były już przedmiotem odrębnych studiów, w niniejszym artykule podsumowano jedynie najważniejsze odkrycia, które w istotny sposób wpływają na problematykę architektury obronnej zakonu krzyżackiego.

ROZPLANOWANIE PRZESTRZENNE. Obserwacje dokonane podczas badań zamków w Grudziądzu, Papowie Biskupim i Wąbrzeźnie zweryfikowały rzuty domów konwentu i przedzamczy. Badania archeologiczne w Papowie Biskupim wykazały, że faktyczny rzut domu konwentu i wielkość przedzamcza znacznie różni się od zaproponowanego przez Conrada Steinbrechta - okazało się, że przedzamcze jest wyraźnie mniejsze. Korekty wymaga również rekonstruowany dotychczas wygląd parchamu. Na szczególną uwagę zasługuje przede wszystkim stwierdzony podczas badań brak fosy oddzielającej przedzamcze od zamku wysokiego, widocznego na rekonstrukcji zamku, proponowanej przez Steinbrechta. Korekcie uległ również układ muru odgradzającego dom konwentu od przedzamcza po północnej stronie zamku. Przy północno-wschodnim krańcu rampy wjazdowej, na przedłużeniu jej muru północnego, prowadzono rozpoznanie murów szyi bramnej z wjazdem na zamek wysoki. Przy zachodnim skraju wykopu odsłonięto ławę fundamentową muru zamykającego szyję bramną od wschodu. Mur ten odchodził od zachowanego północnego odcinka pod kątem prostym i prowadził w kierunku narożnika północno-wschodniego domu konwentu. Nie udało się zarejestrować wschodniego muru przedzamcza. Nowym, nieznanym dotąd elementem zabudowy przedzamcza jest także niewielka piwnica. W odkrywce, usytuowanej w jego północnej części, pozytywnie zweryfikowano jej metrykę - średniowieczną, o kamiennych ścianach i wtórnym, nowożytnym sklepieniu i jej związek z północnym murem przedzamcza. Dodatkową i na razie niezweryfikowaną hipotezą, opartą na wynikach analizy zdjęć systemu LIDAR, jest istnienie drugiego przedzamcza na zachód od domu konwentu. Kwestia ta wymaga jednak dodatkowych badań archeologicznych (il. 2-3) ${ }^{6}$.

\footnotetext{
6 Podsumowanie najnowszych wyników badań zob. Moмot / WAsIK / WiEWIóRA 2014, s. 65-98; Bogusz WasiK, Dzieje budowy i architektura zamku w Papowie Biskupim na ziemi chelmińskiej w świetle ostatnich badań, „Biuletyn Historii Sztuki”, 77, 2015, z. 1, s. 83-101.
} 
W Grudziądzu badania szerokopłaszyznowe, polegające m.in. na odsłonięciu wszystkich zachowanych murów warowni, wykazały, że układ przestrzenny zamku w niewielkim zakresie różnił się od rekonstrukcji zaproponowanej już w latach 40. XX wieku przez Hansa Jacobiego7. Korekcie uległa linia muru w północno-zachodnim narożniku zamku. Odkryto m.in. pozostałości zabudowań przy wschodniej kurtynie zamku, w tym fragment pieca i mury piwnicy. Nowym, nieznanym elementem odsłoniętym w trakcie tych badań był fragment zachodniej części skrzydła południowego z piwnicą, ciągiem komunikacyjnym i filarami. Na podstawie analizy źródeł historycznych (lustracje, wizytacje) oraz wyników badań archeologicznych określono zakres kolejnych etapów budowlanych zamku wraz z przedzamczami (il. 4).

Wyniki badań archeologicznych oraz analiza źródeł historycznych pozwalają na rekonstrukcję funkcji poszczególnych skrzydeł zamku. Najważniejszą częścią domu konwentu w Grudziądzu było skrzydło południowe, w którym mieściła się kaplica zamkowa oraz refektarz. Zabudowa skrzydła wschodniego, powstająca sukcesywnie w ciągu XIV i XV wieku, pełniła funkcje gospodarcze. Znajdowały się tu piekarnia i browar, których pozostałości, datowane na XVI wiek, odsłonięto podczas badań. Północne, najgorzej zachowane, skrzydło zamku pełniło funkcję zamkowej kuchni. W skrzydle zachodnim z kolei znajdowały się m.in. pomieszczenia dormitorium i zamkowe gdanisko ${ }^{8}$.

Badania archeologiczno-architektoniczne zamku biskupów w Wąbrzeźnie wykazały, że podawane dotąd wymiary zamku wysokiego były zawyżone. W rzeczywistości został on wzniesiony w rzucie zbliżonym do kwadratu o wymiarach 36 x 37/38 m². Okazało się, że zarejestrowany podczas badań wykop negatywowy po murze zachodnim wyraźnie wskazuje, iż zewnętrzne lico budowli było proste, a nie załamane, jak w dotychczasowych rekonstrukcjach, w których kurtyna ta, położona na południe od wieży, była wyraźnie cofnięta w stosunku do jej przebiegu po północnej stronie (il. 5-6).

TECHNIKA BUDOWY. Ważnym elementem badań archeologicznych były obserwacje dotyczące technik budowy murów, które zweryfikowały naszą wiedzę dotyczącą charakteru i zakresu historycznych prac budowlanych. Dotyczy to zwłaszcza zamków należących do typu regularnego (Papowo Biskupie, Radzyń Chełmiński), które wznoszono, wykorzystując techniki budowlane polegające

7 Hans JACOBI, Die Ausgrabungsergebnisse der Deutschordensburgen Graudenz und Roggenhausen. Ein Beitrag zur baugeschichtlichen Entwicklung der Ordensburgen, bearb. Udo ARNOLD, Braubach 1996; Marcin WiewióRA, Próba rekonstrukcji etapów budowy i układu przestrzennego zamku, [w:] ZAMEK w GRUDZIĄDZU 2012, s. 361-378; WASIK 2014a, s. 99-112.

8 Podsumowanie wyników badań archeologicznych zob. Marcin Wiewióra, Stan badań archeologiczno-architektonicznych nad zamkiem w Grudziądzu, „Rocznik Grudziądzki”, 24, 2016, s. 37-64.

9 WASIK 2014b, s. 87-98. 
m.in. na skomplikowanych i czasochłonnych niwelacjach terenu. Analizy architektoniczne zachowanych murów zamków typu regularnego w Papowie Biskupim i Radzyniu wyraźnie wskazują, że podczas budowy z góry planowano układ i proporcje wszystkich elementów domu konwentu za pomocą metody ad quadratum ${ }^{10}$. Istotne dla zrozumienia technik budowy murów i etapów realizacji prac budowlanych były też obserwacje wykopów fundamentowych. Analizy stratygrafii warstw wykazały, że zasadnicze etapy budowlane kurtyn zewnętrznych poprzedzone były mniej (Wąbrzeźno) lub bardziej (Radzyń, Papowo) intensywnymi pracami ziemnymi. W Papowie Biskupim budowa zewnętrznej kurtyny obwodowej prowadzona była w przynajmniej trzech etapach (il. 7). W pierwszym wykonano wąskoprzestrzenne rowy fundamentowe. Po wzniesieniu ścian do pewnej wysokości podniesiono poziom gruntu wokół budynku. Wokół zamku powstał płaski taras o szerokości 10-15 m i grubości nasypu przy murze wynoszącym około metr, a na zewnętrznej jego krawędzi - około $3 \mathrm{~m}$. W drugim etapie podniesiono teren o kilka metrów i wyrównano poziom całego dziedzińca. Na podstawie przeprowadzonych wstępnych wyliczeń wydaje się, że na sam dziedziniec i wokół murów domu konwentu naniesiono około $4500 \mathrm{~m}^{3}$ gliny. W przypadku zamku w Radzyniu Chełmińskim stwierdzono, że naokoło zamku wysokiego uformowany został płaski parcham, a poziom terenu nadsypano o 2,5-3 m, tworząc $\mathrm{w}$ ten sposób sztuczną platformę z gliny, na której wzniesione zostały mury. Prace budowlane kurtyn zewnętrznych prowadzone były według przygotowanego wcześniej schematu: na zewnątrz domu konwentu i od strony dziedzińca - w miejscach, w których zaplanowano podpiwniczenia - mury wznoszono sukcesywnie, zaczynając od ław fundamentowych, które wyprowadzano do pewnej wysokości. Od zewnętrznej strony nadsypywano warstwy niwelacyjne, o miąższości do 2,5-3 m. Podobne prace przygotowawcze, chociaż o znacznie mniejszym zakresie, można stwierdzić na przedzamczu wąbrzeskiej rezydencji biskupów chełmińskich. W tym przypadku wyniki badań wykazały, że wzgórze, na którym wzniesiono zamek jest wyniesieniem naturalnym, a nie sztucznym, jak do tej pory sądzono. Poziom nieprzekształconej antropogenicznie warstwy zalegał stosunkowo płytko, co miało bezpośredni wpływ na sposób fundamentowania murów zamkowych. Podczas badań nie stwierdzono stosowania podczas prac budowlanych znaczniejszych niwelacji terenu, natomiast miało to miejsce przy pogłębianiu fosy oraz budowy muru oporowego fosy zamkowej i parchamu. W trakcie prac wykopaliskowych odsłonięto jego niewielki, ale dobrze zachowany fragment. Ślady podobnych działań stwierdzono także na przedzamczu. Badania architektoniczne wykazały również,

10 Szeroko analizuje to Bogusz WasıK, Metoda projektowania zamków konwentualnych na ziemi chelmińskiej. Przyczynek do badań nad zastosowaniem kwadratury w krzyżackim budownictwie zamkowym, „Kwartalnik Architektury i Urbanistyki”, 58, 2013, z. 4, s. 79-91. 
że mury, od strony dziedzińca zamykające południowo-wschodnie i południowo-zachodnie skrzydło zamku, są przewiązane - a zatem wzniesione zostały w tym samym czasie. Wskazuje na to także jednolity system fundamentowania kurtyn. Z tego samego okresu pochodzą mury obwodowe skrzydła głównego od strony dziedzińca oraz przewiązane $z$ nimi ściany działowe w jego wnętrzu ${ }^{11}$.

ANALIZA I CHRONOLOGIA POZIOMÓW OSADNICZYCH. Na podstawie uzyskanych wyników badań nie można jednoznacznie rozstrzygnąć kwestii istnienia (bądź nie) wcześniejszego osadnictwa we wszystkich badanych obiektach $^{12}$. W Papowie Biskupim i Wąbrzeźnie nie stwierdzono ani obecności wczesnośredniowiecznego osadnictwa, ani śladów warowni drewnianych, poprzedzających murowane budowle. $\mathrm{W}$ obu przypadkach nie wskazuje na to zarówno zastosowana technika budowy, jak również brak w pozyskanym materiale zabytkowym jakichkolwiek śladów wcześniejszego osadnictwa. Nie potwierdziły się również hipotezy o istnieniu krzyżackiej drewniano-ziemnej warowni w miejscu późniejszego murowanego zamku wysokiego w Radzyniu Chełmińskim. Analizy murów kurtyny zachodniej tej budowli wykazały, że powstała ona "na surowym korzeniu” razem z pozostałymi murami obwodowymi na sztucznie usypanym wyniesieniu. Domniemana warownia drewniano-ziemna z XIII wieku mogła funkcjonować w miejscu wczesnośredniowiecznego grodu, którego pozostałości zachowały się do dziś kilkaset metrów na południe od południowego przedzamcza.

Istotne z punktu widzenia weryfikacji obecności osadnictwa wczesnośredniowiecznego okazały się wyniki badań prowadzonych w Grudziądzu, gdzie pod późnośredniowiecznymi (krzyżackim) nawarstwieniami, w wykopach eksplorowanych przy wschodniej kurtynie zamku oraz w południowej części wzgórza zamkowego natrafiono na dobrze zachowane fragmenty chaty z paleniskiem, datowane na połowę XI wieku ${ }^{13}$ (il. 8). Odkryto też liczne fragmenty naczyń glinianych datowanych od VIII do początków XIII stulecia oraz inne ślady związane $\mathrm{z}$ funkcjonującą tu osadą podgrodową (?). Badania archeologiczne, prowadzone w ograniczonym zakresie także na dawnym dziedzińcu zamkowym, ujawniły również wyraźne ślady drewnianej zabudowy, będącej prawdopodobnie pozostałością najstarszej warowni krzyżackiej ${ }^{14}$.

11 WasIK 2014b, s. 87-98.

12 Podsumowanie wyników badań zob. Marcin WIEwIóRA, Gród i zamek w państwie krzyżackim - miejsce tradycji czy tradycja miejsca?, „Archaeologia Historica Polona”, 24, 2016, s. $195-231$.

13 Marcin WiewiórA, Stratygrafia kulturowa Góry Zamkowej. Synchronizacja warstw i analiza obiektów kulturowych, [w:] ZAMEK w GRUDZIĄDZu 2012, s. 81-82.

14 Świadczą o tym odkryte podczas eksploracji wykopów sondażowych fragmenty naczyń ceramicznych (tzw. ceramika siwa), datowanych na 2. poł. XIII w. Z uwagi na ograniczony zasięg prac badawczych w tym miejscu trudno jednak określić formę i funkcję odkrytej budowli. 
ROZPOCZĘCIE PRAC BUDOWLANYCH. Korekty wymagają również przyjmowane do tej pory daty rozpoczęcia prac budowlanych, które realizowane były prawdopodobnie później, niż do tej pory zakładano (faza murowana). Badania i krytyczna analiza przekazów historycznych dotyczących zamku w Grudziądzu wykazały, że przyjmowana do tej pory data rozpoczęcia prac budowlanych około 1250 roku jest trudna do utrzymania ${ }^{15}$. Studia podjęte w ostatnim okresie jednoznacznie dowodzą, że najstarsze zachowane dokumenty informujące o istnieniu urzędu komtura grudziądzkiego należy datować na okres między 1263 a 1269 rokiem (il. 8).

Analizy historyczne źródeł dotyczących zamku biskupów w Wąbrzeźnie wskazują natomiast, że budowę murowanego zamku rozpoczęto bezpośrednio przed 1311 rokiem. Przynajmniej część jego wnętrz była gotowa do zamieszkania w 1321 roku, ale całość prac nad wznoszeniem warowni sfinalizowano być może dopiero około połowy XIV wieku. Chronologię dalszych losów tej warowni, przebudów, prac remontowych po zniszczeniach wojennych, znaną z przekazów historycznych, potwierdziły analizy archeologiczne i architektoniczne ${ }^{16}$.

Badania zamku w Papowie Biskupim nie dostarczyły żadnych nowych danych, które ostatecznie wyjaśniłyby chronologię rozpoczęcia jego budowy. Analizy uzyskanego podczas badań materiału ruchomego utrzymały uznawaną dotąd datę rozpoczęcia jego budowy na koniec XIII stulecia.

ANALIZY PRZYRODNICZE. Elementem przeprowadzonych badań archeologiczno-architektonicznych były również analizy specjalistyczne, $\mathrm{w}$ tym badania archeozoologiczne, palinologiczne i dendrochronologiczne. Publikacje dotyczące analiz zwierzęcych szczątków kostnych uzyskanych podczas prac wykopaliskowych w obrębie dawnych zamków krzyżackich są nieliczne (Mała Nieszawka, Malbork i Grudziądz) ${ }^{17}$. Stały się one podstawą do rozważań na temat zaopatrzenia kuchni zamkowych w pożywienie pochodzenia zwierzęcego. Udokumentowano również kwestię spożycia ryb, zarówno słodko- jak i słonowodnych. Pełne opracowanie kości zwierzęcych objęło do tej pory dwa obiekty - zamki w Grudziądzu i w Wąbrzeźnie ${ }^{18}$. Stan zachowania kości odkrytych w Wąbrzeźnie pozwala odtworzyć charakterystyczne menu mieszkańców zamku. Dieta owa była mocno urozmaicona - znajdowały się w niej nie tylko wołowina, wieprzowina, baranina i kozina, ale także kilka gatunków ptactwa i ryb. W przypadku ptactwa stwierdzono bardzo wysoki udział drobiu (gęsi i kur).

15 JóŹWIAK / TRUPINDA 2012.

16 ZAMEK BISKUPÓW w WĄBRZEŹNIE 2014.

17 Marzena Makowiecka, Daniel Makowiecki, Mirosława Zabilska, Wyniki badań archeozoologicznych, [w:] ZAMEK w GRUDZIĄDZU 2012, s. 302-351.

18 Marzena Makowiecka, Daniel Makowiecki, Mirosława Zabilska, Wyniki badań zwierzęcych szczq̨tków kostnych, [w:] ZAMEK BISKUPów w WĄBRZEŹNIE 2014, s. 177-201. 
Z dzikiego ptactwa przeważały: gęgawa, krzyżówka, cyranka, cyraneczka, czernica i lodówka, a więc gatunki, które gnieżdżą się nad jeziorami i stawami w zaroślach wodnych. Wśród ryb stwierdzono głównie szczątki szczupaka i lina - gatunków typowych dla jezior o urozmaiconej i płytkiej linii brzegowej. Wyjątkowo konsumowano jesiotry oraz dorsze, czyli ryby transportowane $\mathrm{z}$ dalszych odległości, poławiane w Wiśle lub Drwęcy oraz w Morzu Bałtyckim. Podobne obserwacje dotyczyły struktury spożycia mięsa mieszkańców zamku grudziądzkiego. Dodatkowo podczas badań odkryto 104 fragmenty szczątków kostnych ryb. Dominowały ryby karpiowate. Stwierdzono również obecność leszcza, płoci/wzdręgi, okoniowatych. Z pozostałych gatunków zidentyfikowano szczupaka i suma. Analizy w zakresie badań przyrodniczych objęły również zamek w Papowie Biskupim, w którym na ścianach obwodowych domu konwentu (zarówno od wewnątrz, jak i od zewnątrz) zachowały się otwory maculcowe (il. 3). W wielu z nich stwierdzono pozostałości drewnianych belek rusztowań. Badania wykazały, że w trakcie budowy zamku stosowano rusztowania jednosztandarowe. Na podstawie analizy pozyskanych próbek drewna ustalono, że należą one do wiązu. Jest to gatunek drewna często spotykany w naszej strefie geograficznej, szczególnie odporny na gnicie, w środowisku leśnym występujący nad rzekami i potokami, w zasięgu wód powodziowych. Z trzech innych otworów pozyskano próbki należące do wiązu i jesionu. Żadna z nich nie nadaje się do analiz dendrochronologicznych.

W kontekście analiz palinologicznych interesujących informacji dostarczyło badanie pyłków zebranych w trakcie badań wzgórza zamkowego w Grudziądzu. Były one istotne dla zrozumienia zmian środowiska w okresie poprzedzającym ekspansję zakonu krzyżackiego na ziemi chełmińskiej i stanowią ważny element szerszego programu badawczego zajmującego się tzw. ekologią krucjat ${ }^{19}$. Dzięki tym badaniom możliwa była wstępna charakterystyka środowiska osady wczesnośredniowiecznej przed przybyciem Krzyżaków. Dane makrobotaniczne wykazały, że w pobliżu tej osady znajdowały się przestrzenie trawiaste i strefy podmokłe $^{20}$.

Podczas badań w Wąbrzeźnie pobrano cztery próbki zawierające szczątki drewna: z warstw związanych z różnymi miejscami i poziomami użytkowymi zamku (w 2010 roku) i z przedzamcza (w 2011 roku). W badanym materiale rozpoznano dwa taksony należące do drzew liściastych i szpilkowych. Szczątki sosny oznaczono w trzech, szczątki wierzby w jednej próbie ${ }^{21}$.

19 Suzan Carson, Lisa Shillito, Alex Brown, Aleksander Pluskowski, Environmental Assesment of Samples from the Castle Site at Grudziądz, Poland, [w:] Zamek w Grudziądzu 2012, s. 351-358.

20 TAMŻE, s. 392.

21 Dorota BIENIAs, Wyniki analizy szczatków drewna, [w:] ZAMEK BISKUPów w WĄBRzeźNIE 2014, s. 202-206. 


\section{Wnioski}

Prace badawcze realizowane w ostatniej dekadzie na kilku wybranych obiektach warownych ziemi chełmińskiej dostarczyły przede wszystkim informacji na temat technik i warsztatu budowlanego, dając podstawę do nowych rekonstrukcji warowni oraz etapów ich budowy ${ }^{22}$. W przypadku obiektu w Grudziądzu udało się również określić zasięg i chronologię wczesnośredniowiecznych poziomów osadniczych poprzedzających budowę warowni. Potwierdzono w ten sposób istnienie osadnictwa wczesnośredniowiecznego na Górze Zamkowej, chociaż nie udało się w sposób jasny zdefiniować jego charakteru (osada grodowa?). Z kolei badania archeologiczne prowadzone na zamku w Radzyniu Chełmińskim nie potwierdziły wcześniejszego osadnictwa w miejscu, w którym powstał dom konwentu.

Z przeprowadzonych analiz architektonicznych wynika, że początkowe etapy wznoszenia murowanych budowli obronnych przebiegały nierównomiernie i uzależnione były od wielu czynników związanych m.in. z uwarunkowaniami lokalnymi - topografią, środowiskiem. Dotyczy to zwłaszcza grupy zamków tzw. nieregularnych (Grudziądz), które - jak wskazują analizy architektoniczne i archeologiczne - powstawały sukcesywnie, początkowo jako jednoskrzydłowe warownie. W kolejnych etapach budowlanych powstawała zabudowa wzdłuż kolejnych skrzydeł zamku, a ostateczny kształt warownie te osiągały po blisko stuleciu od rozpoczęcia prac budowlanych ${ }^{23}$. Istotne w przypadku tej grupy zamków było z pewnością starannie dobrane miejsce, na którym wznoszono kolejne elementy założenia. Zamek w Grudziądzu został zbudowany na naturalnym wyniesieniu, zapewniającym maksimum bezpieczeństwa już na etapie powstawania domu konwentu. W tym przypadku odpowiedni dobór miejsca pod zamek wysoki i przedzamcze był świadomą i starannie przemyślaną decyzją, która w maksymalnym stopniu wykorzystała naturalne walory topograficzne terenu.

Zamki z grupy tzw. regularnych (najstarszy - Papowo Biskupie i tzw. klasyczny kasztel - Radzyń Chełmiński) powstawały z kolei według z góry określonego projektu. W tych przypadkach analizy zachowanych murów potwierdziły, że były to realizacje od początku logicznie i konwekwentnie zaplanowane. Analizy preprowadzone na zamku w Radzyniu Chełmińskim wykazały, że zasadnicze prace budowlane na tym miejscu poprzedzily intensywne prace ziem-

22 Podsumowanie kwestii technik budowlanych zob. Bogusz WASIK, Marcin WiEWIÓRA, Castle building techniques in the Teutonic Order's State in Prussia based on examples of selected convent houses in the Chetmno Land, in the light of recent studies, "Castellologica Bohemica”, 15, 2015, s. 74-93.

23 Wiewióra 2012, s. 363-364. 
ne polegające na przygotowaniu sztucznie ukształtowanego plateau, na którym prawdopodobnie w pierwszej dekadzie XIV wieku wzniesiono zamek wysoki. Prace niwelacyjne realizowano zarówno przed, jak i w trakcie wznoszenia kolejnych kurtyn, poprzez nadsypywanie warstw gliny po obu stronach powstających sukcesywnie kurtyn zewnętrznych i murów działowych warowni. Podobną sytuację stwierdzono na zamku w Papowie Biskupim, wykluczając także i w tym przypadku możliwość funkcjonowania w tym miejscu wcześniejszego grodu. W grubej, osiągającej miejscami ponad $5 \mathrm{~m}$ warstwie nasypowej, stwierdzonej na dziedzińcu zamku oraz w wykopach założonych wokół budowli, nie znaleziono żadnych śladów świadczących o starszym osadnictwie. Mury zamku wzniesiono na wcześniej niezamieszkanym wyniesieniu. Nie udało się potwierdzić istnienia wcześniejszej osady grodowej pod pozostałościami rezydencji biskupów chełmińskich w Wąbrzeźnie. Szczegółowe analizy architektoniczne stały się podstawą zaproponowanych wirtualnych rekonstrukcji zamków w Grudziądzu i Wąbrzeźnie (il. 9-10).

\section{Marcin Wiewióra}

The Institute of Archeology, Nicolaus Copernicus University in Toruń

\section{Teutonic Castles in the Kulmerland - new sources and new perspectives}

Since 2005 a new research project is being undertaken at the Institute of Archeology of the University of Mikołaj Kopernik in Torun. The project seeks to provide answers to basic questions concerning the early stages of the development of the Teutonic defensive brick architecture in the Culm region (Kulmerland). Particular focus in on establishing the beginning of the Teutonic building activity in the region, as well as on the chronology and presence of settlements predating the arrival of the Teutonic knights, the shape and form of the oldest stone and brick buildings, the position and function of the chambers, material culture and methods of construction.

This paper presents a summary of the major results of ten years of research, during which time five structures were examined to a various degree. That is the castle in Papowo Biskupie, fragment of the western section of the castle in Radzyń Chełmińs$\mathrm{ki}$, the house of the Teutonic convent in Grudziądz, the inner and outer castle of the Culm bishops in Wąbrzeźno, and the convent's castle in Kowalewo Pomorskie. The extent of undertaken research varied for the different structures. Large-scale excavations were conducted in the castles in Grudziądz, Radzyń Chełmiński, Papowo Biskupie, and Kowalewo Pomorskie as well as Wąbrzeźno. Test trenches were excavated in the outer castles in Wąbrzeźno and Papowo Biskupie. The excavations were complemented by geological core drilling, which was carried out during the initial terrain study (Wabrzeźno, outer castle), and during geological work necessary for specialised analysis of the natural environment and environment reconstruction (convent in Grudziądz, convent and 
Papowo Biskupie, the southern parcham inter-wall area and outer castle). The most important issues considered during the research were: whether castles were constructed on the sites of previous fortified settlements; what were the different construction phases of the examined castles (wooden, brick / stone) and whether the oldest (irregular castles) were constructed using the same methods and technology as newer, regular structures, and finally what these methods consisted in. 


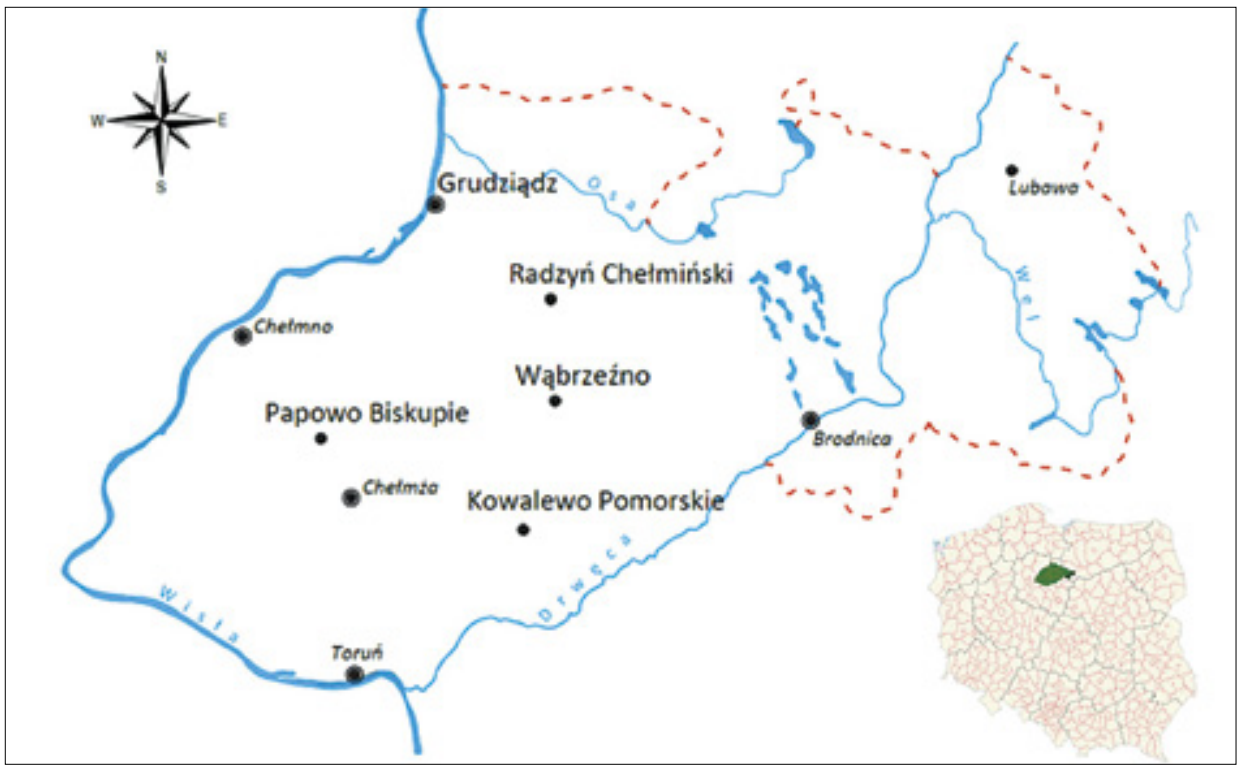

Il. 1. Ziemia chEŁmIŃsKA - lokalizacja zamków. Oprac. B. Wasik

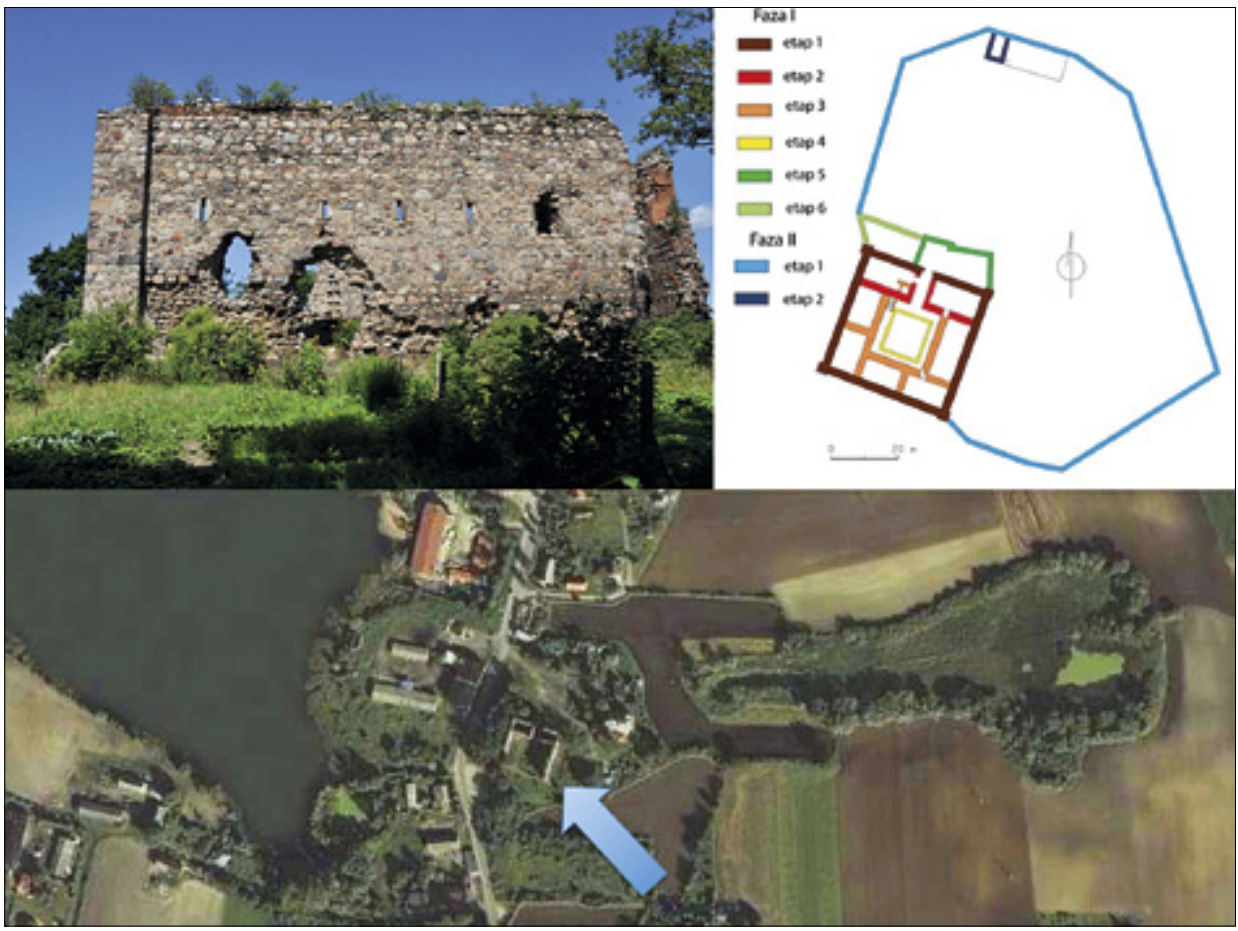

Il. 2. PApowo BiskupIE, zamek kapitulny. Widok skrzydła wschodniego, rozwarstwienie chronologiczne murów i widok zamku z lotu ptaka. Fot. W. Miłek; oprac. etapów budowy B. Wasik; widok z lotu ptaka wg Google Maps 


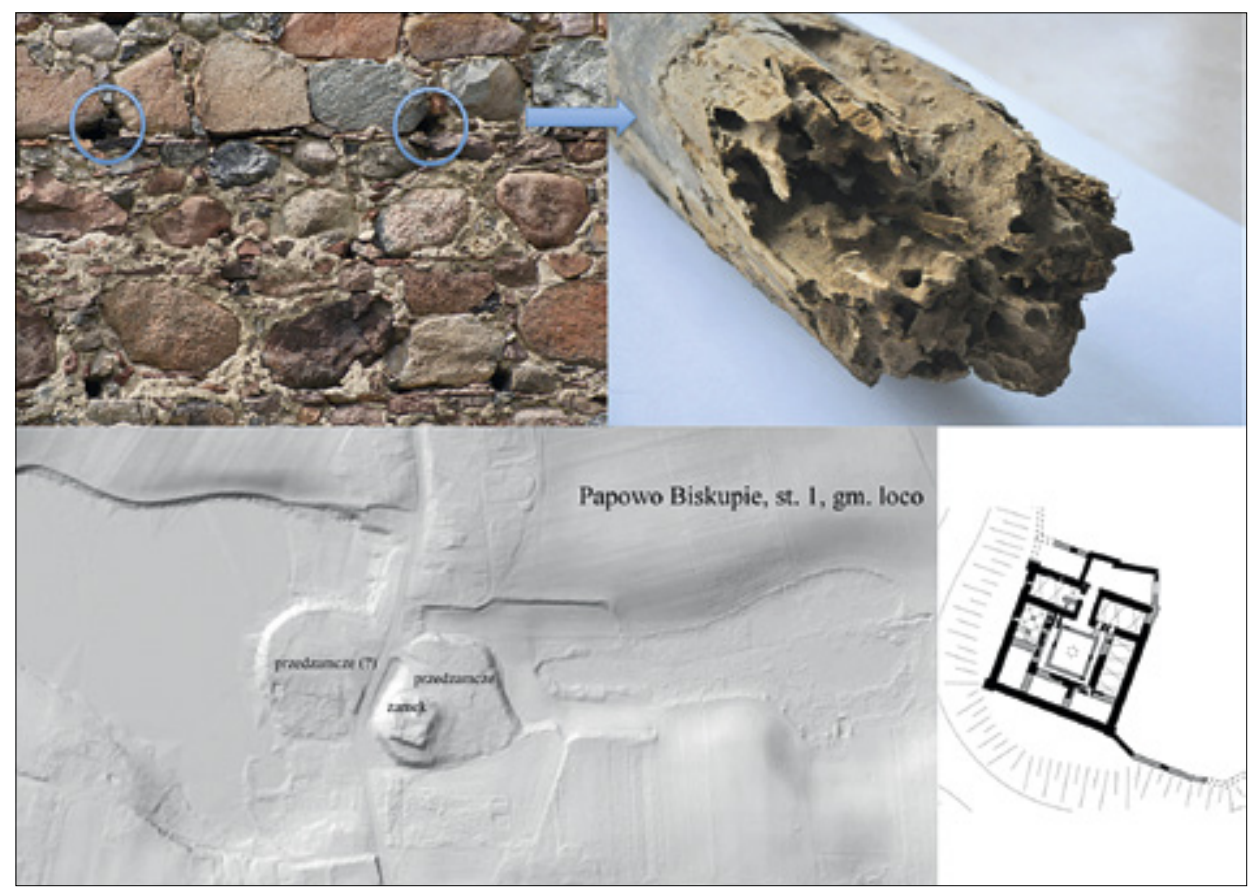

Il. 3. PApowo BiskupIE, zamek kapitulny. Otwory maculcowe z fragmentem rusztowania; widok domniemanego drugiego przedzamcza i rekonstrukcja rzutu zamku głównego po badaniach archeologiczno-archtektonicznych. Oprac. B. Wasik; fot. B. Wasik; widok z lotu ptaka wg LIDAR

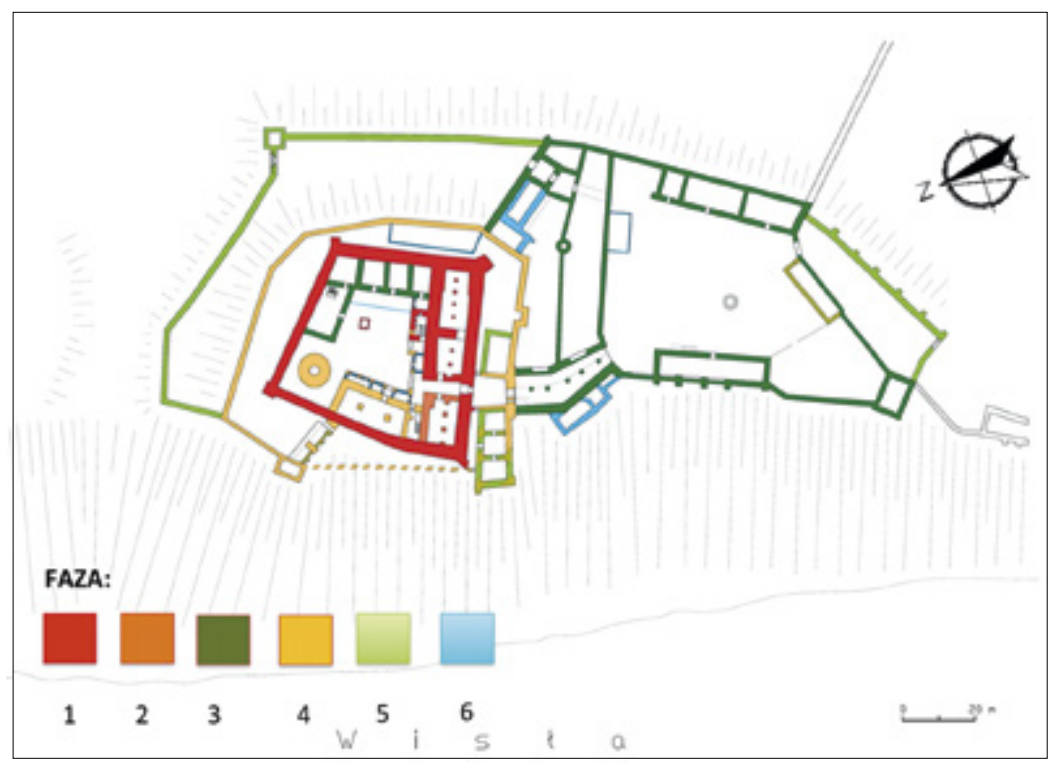

Il. 4. GRUDZIĄDZ, zamek konwentualny. Etapy budowy zamku i przedzamczy. Oprac. B. Wasik 


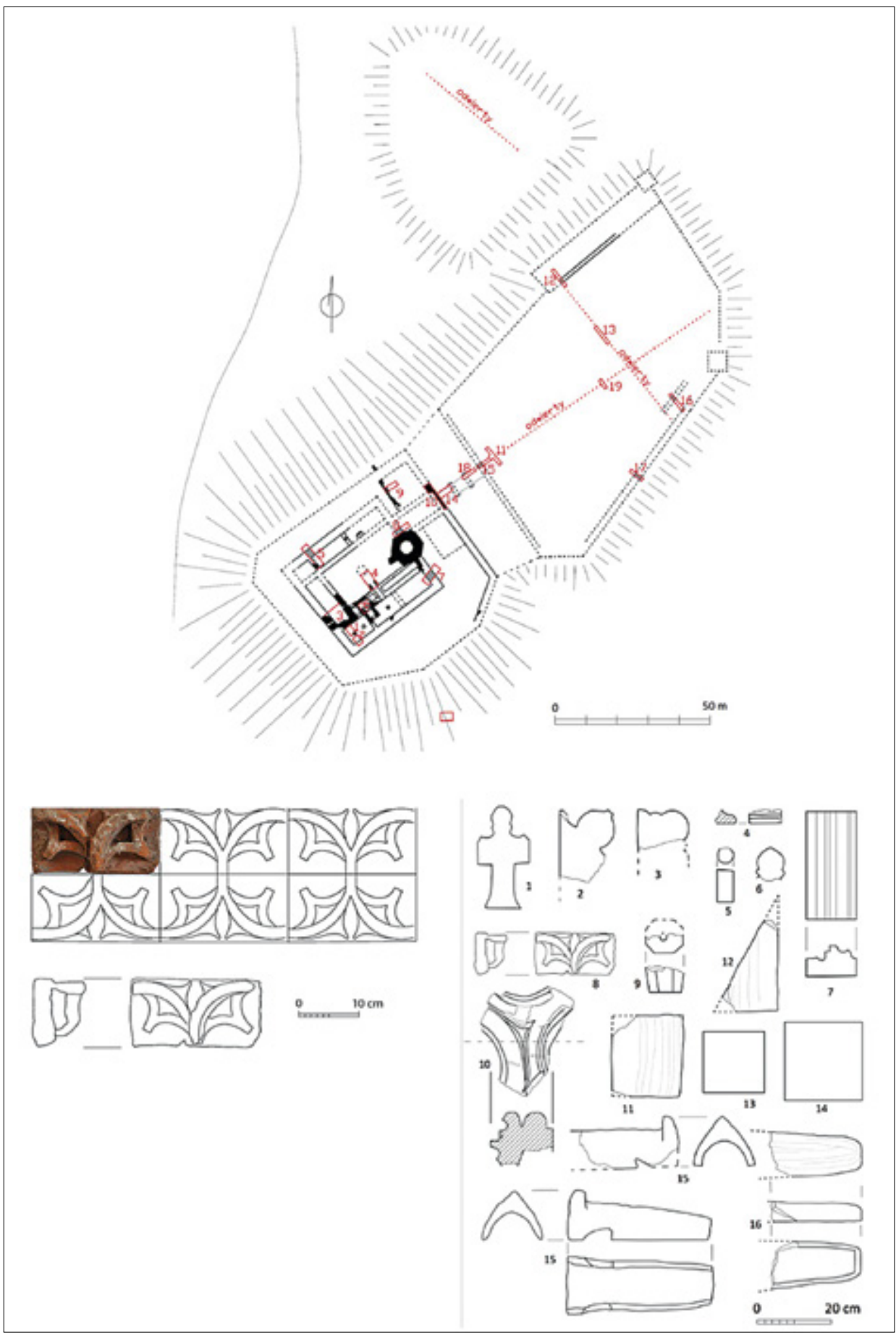

Il. 5. WĄBRZEŹNo, zamek biskupi. Lokalizacja odwiertów i wykopów; zestawienie detalu architektonicznego odkrytego podczas badań archeologicznych. Oprac. B. Wasik 


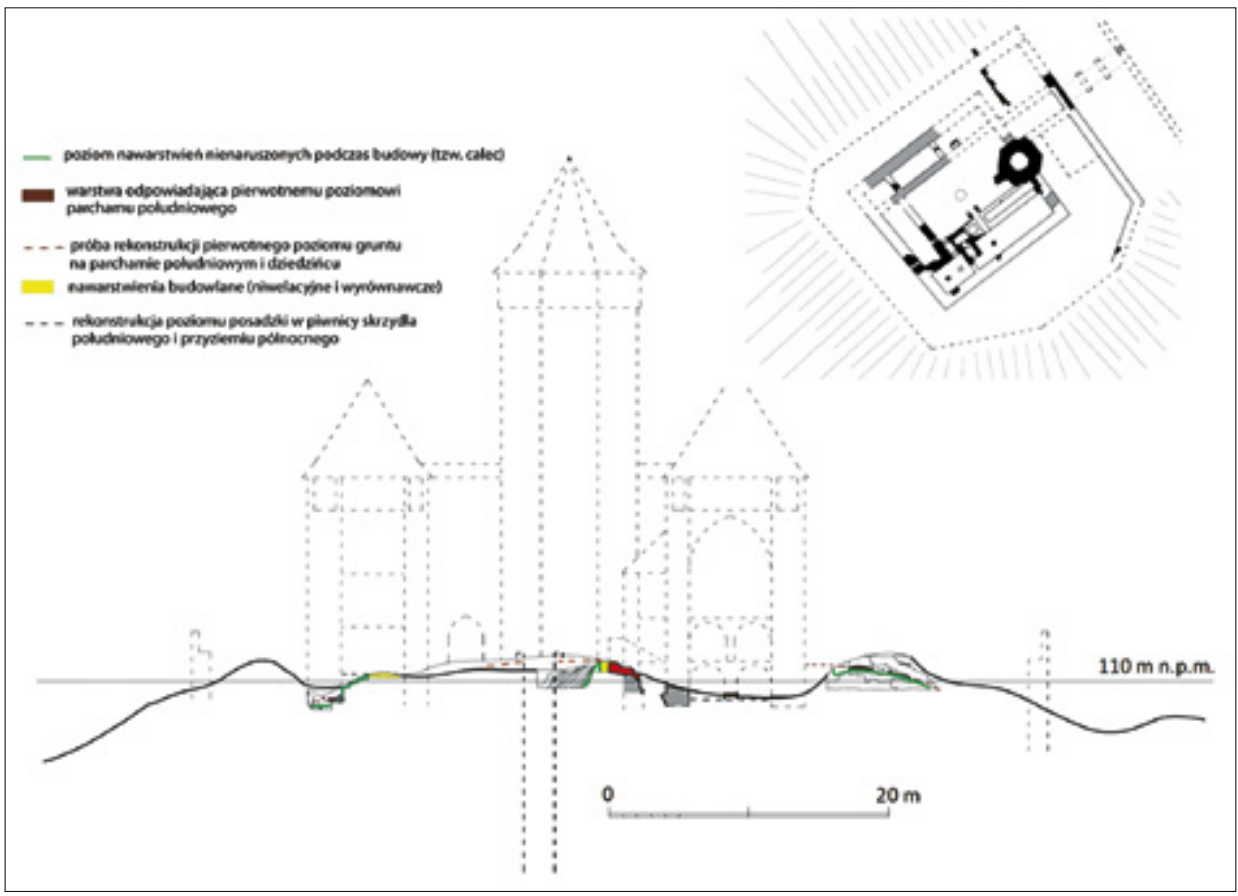

Il. 6. WąBRZEŹNo, zamek biskupi. Przekrój poprzeczny przez wzgórze zamkowe (na osi północ-południe) i rekonstrukcja rzutu zamku wysokiego. Oprac. B. Wasik

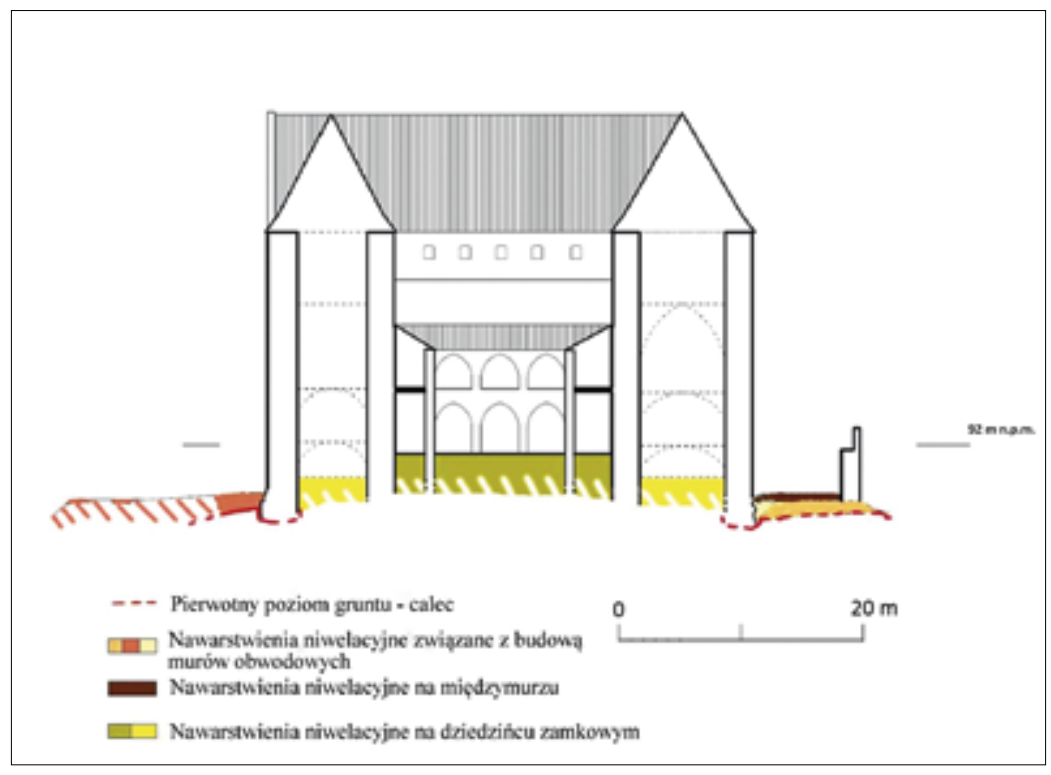

Il. 7. Papowo BiskupIE, zamek kapitulny. Przekrój poprzeczny wzdłuż osi północ-południe - nawarstwienia niwelacyjne. Oprac. B. Wasik 


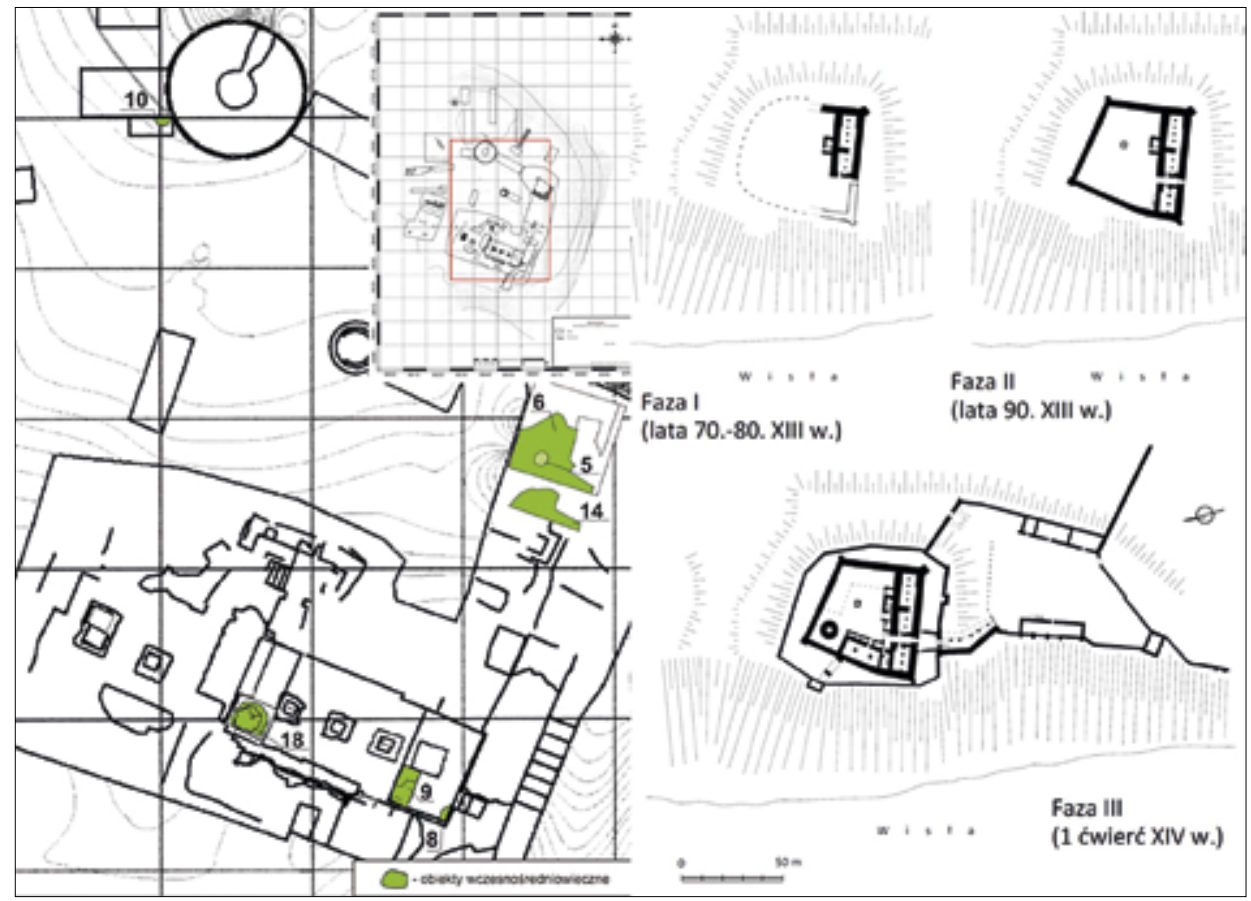

Il. 8. GRUDZIĄDZ, zamek konwentualny. Lokalizacja pozostałości osady wczesnośredniowiecznej na wzgórzu zamkowym; rekonstrukcja etapów budowy zamku wysokiego. Oprac. W. Miłek, B. Wasik 


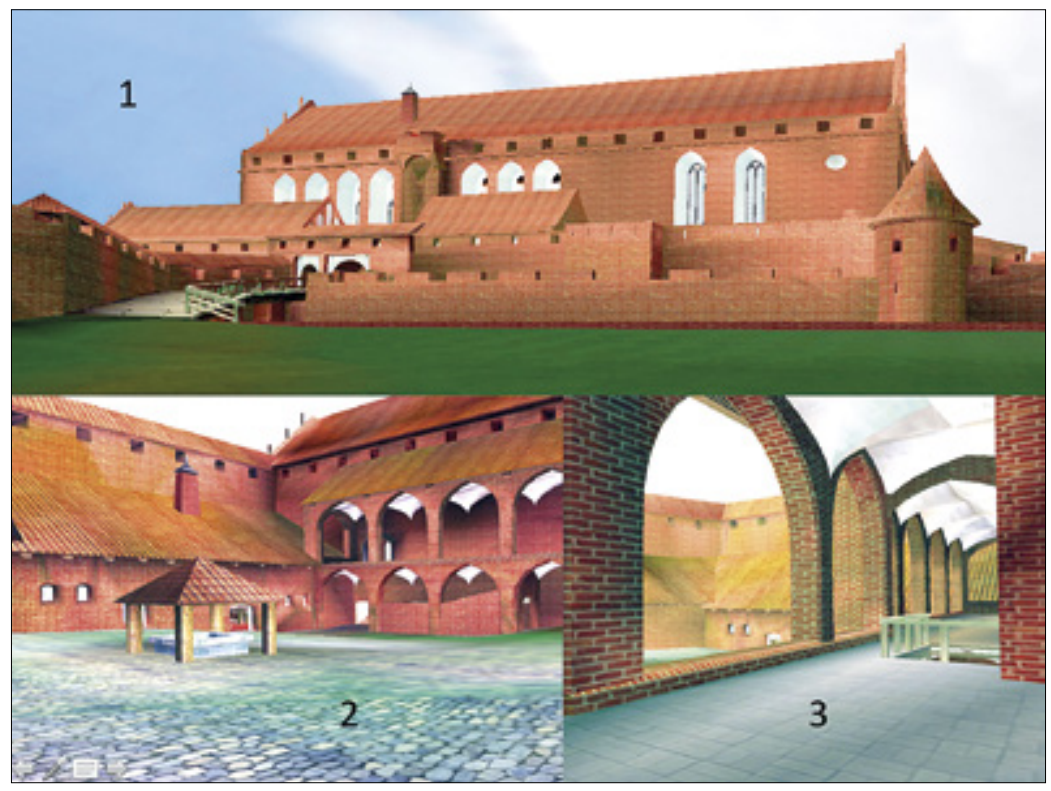

Il. 9. GrudziąDz, zamek konwentualny. Wizualizacja 3D zamku wysokiego. Oprac. J. Matus, B. Wasik

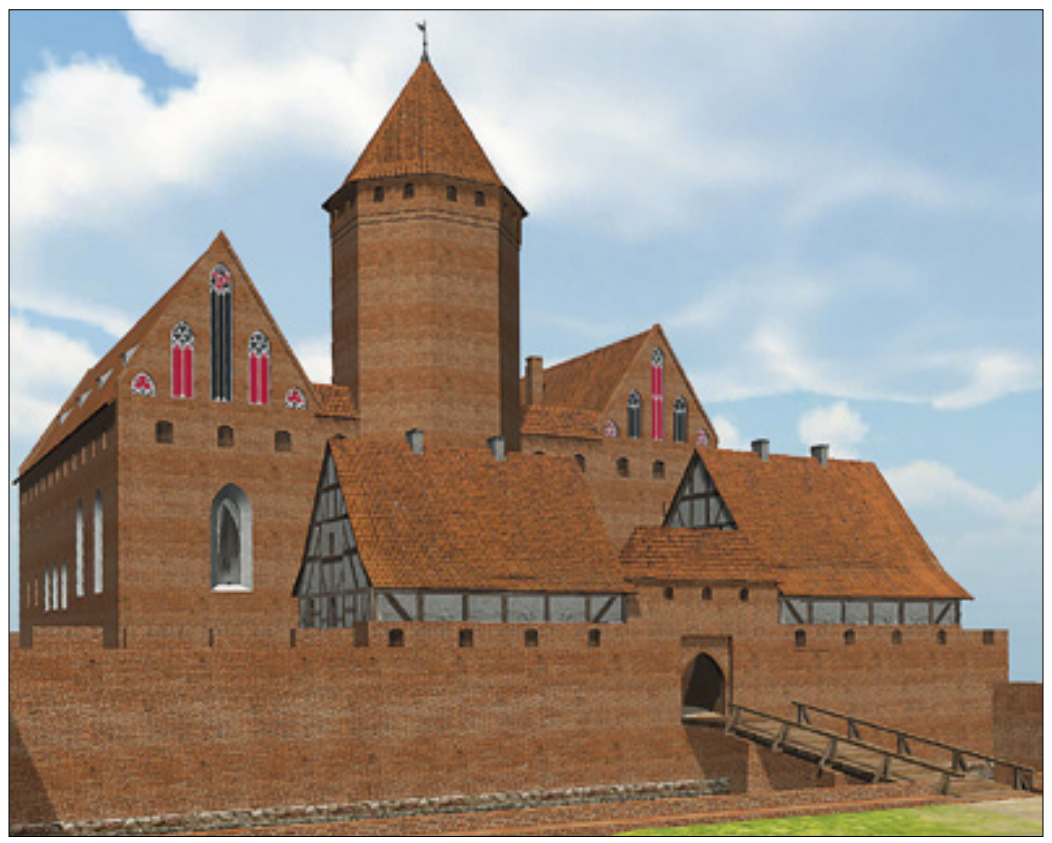

Il. 10. WĄBRZEŹNo, zamek biskupi. Wizualizacja zamku wysokiego. Oprac. P. Moszczyński, B. Wasik 